\section{Privatization for NIH?}

Floating off intramural research at NIH is not altogether a bad idea.

The infectious fashion for turning over public assets to private ownership, inelegantly called privatization by the British government (which claims to have invented the notion), seems now to have touched even the US National Institutes of Health (NIH). By all accounts (or at least by that of the New York Times last week), the Office of Management and Budget (OMB) has been working on a proposal for turning the part of NIH that carries out research in-house into a private institution, a kind of research university under independent management. The first reactions to the news, in Congress and elsewhere, have been expressions of alarm; why tamper with success? But the proposal deserves more careful attention than a reaffirmation of the comforts of the status quo. The acid test of OMB's proposal should be a considered evaluation of the benefits and disadvantages of radical change.

The organization is at present two things - a biomedical research organization and, by delegation, the US government's chief grant-making agency for biomedical research. For the past several decades, both activities have been helped to grow by the good will of a well-meaning Congress, which habitually appropriates more money for NIH than the administration requests. But congressional indulgence for NIH is alloyed with an inclination to interfere, both in the management of NIH's in-house research and in their structure, with repeated special pleading on behalf of diseases newly drawn to the attention of interested congressmen. At various times, moves of this kind have threatened seriously to skew the balance of NIH's in-house activity and to cramp the institutes' flexibility. The status quo abounds with danger, which is another reason why those concerned for the welfare of NIH should not too quickly scorn OMB's initiative.

At the same time, the considerations that have apparently prompted the proposals are not in themselves a sufficient justification for such a radical change. $\mathrm{NIH}$ are said to be concerned that their status as a part of the public service, which requires that in-house researchers earn government salaries, will lead to the loss of able people to other institutions able to offer more. Dr Robert Gallo's flirtation over several months with universities and commercial companies is said to have brought the issue to a head. But there is no good reason why NIH's constitution should be changed simply to keep able people within its walls. Might it not, on the contrary, be that an important part of NIH's social function is to populate university and other research laboratories with able leaders? If Gallo ends up at Johns Hopkins or Duke universities, or even somewhere else, NIH's loss will be some other institution's gain.

It matters more that, if NIH's in-house research became the responsibility of a private corporation, able to decide for itself on the balance (and even the location) of its research, Congress might get even better value for the $\$ 600$ million plus now spent of these activities (just over 10 per cent of the total budget). Moreover, in-house NIH would then be able to play a fuller part in the educational life of the United States than they do at present. The other side of that coin is, however, plain. Would an independent research organization of such great size continue to enjoy the favours of the US Congress if it were competing for public funds with other private institutions, universities for example, to which congressmen may have conflicting constituency loyalties? If, on the other hand, private NIH would have to raise their own funds from the grant-making part of the present organization and from private sources, would their future seem secure enough to satisfy even the researchers who now envy the higher salaries obtainable elsewhere? Left to themselves, NIH would probably settle for the status quo. Much will depend, in the months ahead, on the extent to which OMB persuades itself (and others) that making in-house NIH compete with others for research support would markedly enhance the quality of research. Experience elsewhere, in Britain for example, shows that a little uncertainty can be beneficial but that too much of its is damagingly distracting.

\section{Research for industry}

The British government wants industry to pay for public development, but should go carefully.

SuCCESSIVE British governments have wrung their hands over the reluctance of British companies to invest a greater share of their resources in research and development. The present government is no exception, but its exhortations have not been conspicuously more effective than those of others. That, together with the wish to free resources for basic research, explain why it has now embarked on a scheme for shifting from its own budget the cost of civil research judged to be so much in the nature of development, rather than research, that it could reasonably be paid for by its eventual users.

The Cabinet Office is in the middle of a review of government spending on what it calls "near-market" research, among which the Department of Energy's support of nuclear power developments is conspicuous, but which touches all kinds of government activities in fields as different as agriculture and information technology. The underlying objective seems to be not merely economy but the application of an extension of the Rothschild principle of the 1970s: research and development with industrial application is likely to be the more effective when the putative beneficiaries have to pay for it.

The most obvious danger stems from the simple truth that industrially orientated research is likely to be most effective not merely when the beneficiaries pay for it, but when they actually carry it out themselves, privately (for the sake of commercial secrecy) and in circumstances in which researchers and salesmen rub shoulders easily. Most companies faced with the prospect of having to pay for research carried out in public laboratories ostensibly on their behalf will prefer to do the work themselves, even at much greater cost. So enforcement of the extended Rothschild principle may indeed have the effect of generating a greater volume of in-house research by forward-looking companies. But the more immediate consequence may be further to shrink the volume of work at government research laboratories, with more putting-out to grass of able researchers and the like.

Moreover, there are some fields in which the principle is plainly inapplicable. Agriculture is one; it would be inefficient and probably inequitable if the government should seek to recover the costs of applied agricultural research in some of the obviously tempting ways, a levy on farm produce for example, while making food manufacturers and retailers pay for it will break the crucial link between research and its beneficiaries.

At the other end of the spectrum, nuclear power is another field in which continued public investment is, on present policies, essential. Britain, like most other producers of nuclear power except the United States, reprocesses irradiated fuel so as to extract plutonium and the other actinides from irradiated uranium, both for the sake of the extra energy that may be wrung from them and because incinerating long-lived fissile material in fast reactors is the safest way of disposing of it. The result is that Britain, like other European states, spends public money on the development of fast reactors. But is that not a "near-market" activity whose cost could be be spun off to the Central Electricity Generating Board? That is what the government will argue. The other side of that argument is that the government, which has endorsed the policy of reprocessing uranium, needs itself to be informed by a fast-breeder research programme if only to keep intelligently in mind the wisdom of its policy. What all this implies is that there are probably fewer opportunities for wise economies than appear at first sight. 